\title{
Analisis Laba, Arus Kas Operasi Dan Nilai Buku Ekuitas Terhadap Harga Saham
}

\author{
Eva Mufidah \\ Universitas Merdeka Pasuruan \\ eva.moev@gmail.com
}

Diserahkan: 8 Pebruari 2017, Diterima: 20 Maret 2017

\begin{abstract}
Parameter to measure the performance of companies in this study is the profit, operating cash flow and book equity. This study aimed to obtain information profit, operating cash flow and book equity of the stock price. The study was conducted by purposive sampling of 40 companies listed on the Stock Exchange during the period 2011-2014. This study uses a quantitative approach to the multiple regression analysis. The analysis showed that profit and operating cash flows have a significant effect on stock prices, while the book equity is not significant effect on stock prices.
\end{abstract}

Keywords: profit, operational cash flow, book equity, share price

\section{abstrak}

Parameter untuk mengukur kinerja perusahaan dalam penelitian ini adalah laba, arus kas operasi, dan nilai buku ekuitas.Penelitian ini bertujuan untuk memperoleh informasi laba, arus kas operasi, dan nilai buku ekuitas terhadap harga saham. Penelitian dilakukan secara purposive sampling terhadap 40 perusahaan manufaktur yang terdaftar di BEI selama periode 2011-2014. Penelitian ini menggunakan pendekatan kuantitatif dengan analisis regresi berganda. Hasil analisis menunjukkan bahwa laba dan arus kas operasi berpengaruh signifikan terhadap harga saham, sedangkan nilai buku ekuitas tidak berpengaruh signifikan terhadap harga saham.

Kata kunci: laba, arus kas operasi, nilai buku ekuitas, harga saham

\section{A. PENDAHULUAN}

Pasar modal memiliki peran besar bagi perekonomian suatu negara. Pasar modal memiliki fungsi ekonomi karena menyediakan fasilitas atau wahana yang mempertemukan dua kepentingan yaitu pihak yang memiliki kelebihan dana (investor) dan pihak yang memerlukan dana (issuer). Dengan adanya pasar modal maka pihak yang memiliki kelebihan dana dapat menginvestasikan dana tersebut dengan harapan memperoleh imbalan (return) sedangkan pihak issuer (perusahaan) dapat memanfaatkan dana tersebut untuk kepentingan investasi tanpa harus menunggu tersedianya dana dari operasi perusahaan. Pasar modal dikatakan memiliki fungsi keuangan, karena pasar modal memberikan kemungkinan dan kesempatan memperoleh imbalan (return) bagi pemilik dana.

Alasan penelitian ini dilakukan karena harga saham merupakan dasar pertimbangan investor dalam menentukan keputusan berinvestasi. Keputusan investor apakah akan membeli atau menjual saham yang dimiliki didasarkan pada bagaimana kondisi harga saham saat itu. Selain itu penelitian ini dilakukan karena adanya perbedaan hasil penelitian yang satu dengan penelitian yang lainnya. Penelitian Amalia (2010) membuktikan bahwa laba secara positif berpengaruh terhadap harga saham. Hasil penelitian ini juga didukung oleh Arifah (2013), serta Ibrahim (2011) menyatakan bahwa laba berpengaruh positif dan signifikan terhadap harga saham. Sedangkan penelitian menurut Kwon (2009) menyatakan bahwa laba tidak berpengaruh positif terhadap harga saham.Adanya hasil yang beragam mengenai hubungan laba, arus kas operasi dan nilai buku ekuitas terhadap harga saham, maka penelitian ini bermaksud meneliti kembali penelitian terdahulu. Namun demikian terdapat perbedaan kurun waktu penelitian yaitu rentang waktu penelitian selama 4 tahun (2011-2014). Sehingga penelitian ini memberikan kontribusi untuk menguji apakah terjadi penguatan konsistensi terhadap teori atau sebaliknya.

Penelitian ini menguji dan menganalisis pengaruh laba, arus kas operasi dan nilai buku ekuitas terhadap harga saham pada perusahaan manufaktur. Semakin berkembang suatu 
perusahaan maka dana yang dibutuhkan semakin besar. Oleh karena itu, perusahaan harus giat mencari sumber-sumber yang dapat menyediakan dana dalam jumlah besar. Salah satu cara yang digunakan yaitu mencari dana melalui pasar modal. Terdapat beberapa pengertian pasar modal, diantaranya menurut Undang-undang Pasar Modal No. 8 Tahun 1995, pasar modal adalah kegiatan yang bersangkutan dengan Penawaran Umum dan perdagangan Efek, Perusahaan Publik yang berkaitan dengan Efek yang diterbitkannya, serta lembaga dan profesi yang berkaitan dengan efek.

\section{B. KAJIAN PUSTAKA}

Menurut Amalia dan Sulistyowati (2007), nilai buku ekuitas merupakan ukuran neraca atau aset bersih yang menghasilkan laba. Nilai buku ekuitas per lembar saham menunjukkan aset bersih yang dimiliki oleh pemegang saham dengan memiliki satu lembar saham. Karena aset bersih adalah sama dengan total ekuitas pemegang saham, maka nilai buku ekuitas per lembar saham adalah total ekuitas dibagi dengan jumlah lembar saham yang beredar.Nilai buku ekuitas dapat diartikan sebagai nilai saham menurut pembukuan perusahaan emiten. Menurut Anggono dan Baridwan (2003), dalam penelitiannya, mengekspresikan nilai perusahaan sebagai fungsi laba dan nilai buku ekuitas. Informasi mengenai nilai buku ekuitas akan bermanfaat bagi investor sebagai pertimbangan untuk melakukan transaksi saham.

Triyono dan Hartono (2000) yang meneliti tentang kandungan informasi arus kas, laba dengan harga atau return saham menggunakan dua pendekatan model level dan return. Hasil analisis menunjukkan bahwa pemisahan tiga komponen arus kas yaitu arus kas dari aktivitas pendanaan, investasi, dan operasi mempunyai pengaruh yang signifikan dengan harga saham kecuali arus kas investasi. Gantyowati (2001) menguji kandungan informasi arus kas dari aktivitas operasi dan data akrual terhadap return saham di Bursa Efek Jakarta. Hasil penelitian tersebut menunjukkan adanya hubungan yang signifikan antar komponen earnings. Adanya hubungan tersebut menunjukkan bahwa cash flow mempunyai kandungan informasi.Berdasarkan beberapa dukungan fakta empiris tersebut, dapat dibuat suatu kesimpulan bahwa informasi arus kas dapat berpengaruh positif ataupun negatif terhadap harga saham, tergantung kemampuan perusahaan dalam menghasilkan kas dan setara kas serta memungkinkan pemakai mengembangkan model untuk menilai dan membandingkan nilai sekarang dari arus kas masa depan (future cash flows).

Berdasarkan uraian tersebut, jelas bahwa perhatian investor atau pihak-pihak tertentu sering terpusat pada informasi laba tanpa memperhatikan prosedur yang digunakan untuk menghasilkan informasi laba.Hal ini memberikan peluang kepada manajer untuk melakukan manipulasi atas laba atau lebih dikenal dengan earnings management yang pada akhirnya akan mempengaruhi kualitas laba yang dihasilkan. Manajemen laba tersebut dapat terjadi karena manajer diberi keleluasaan untuk memilih metode akuntansi yang akan digunakan dalam mencatat dan mengungkapkan informasi keuangan privat yang dimilikinya. Selain itu perilaku manipulasi ini juga terjadi karena adanya asimetri informasi (information asymmetry) yang tinggi antara manajemen dan pihak lain yang tidak mempunyai sumber, dorongan, atau akses yang memadai terhadap informasi untuk memonitor tindakan manajer. Laba yang kurang berkualitas bisa terjadi karena dalam menjalankan bisnis perusahaan, manajemen bukan merupakan pemilik perusahaan. Rendahnya kualitas laba akan dapat mengakibatkan kesalahan dalam pembuatan keputusan bagi para pemakainya seperti investor dan kreditor, sehingga nilai perusahaan akan berkurang.Berdasarkan uraian tersebut, penelitian ini termotivasi untuk menelaah apakah informasi laba, yang secara umum masih merupakan obyek manipulasi manajer, masih menjadi informasi utama bagi investor di Indonesia dalam mengambil keputusan. Dengan adanya kelemahan informasi laba tersebut, penelitian ini mencoba mengangkat informasi pembanding selain informasi laba yaitu informasi arus kas dan nilai buku ekuitas. Dengan adanya informasi tersebut, diharapkan bisa 
diketahui apakah investor di Indonesia sudah cukup sophisticated dalam mengelola informasi akuntansi yang terdapat pada laporan keuangan perusahaan.Tujuan dari penelitian ini yaitu menguji dan menganalisis pengaruh laba, arus kas operasi dan nilai buku ekuitas terhadap harga saham pada perusahaan manufaktur.

\section{METODE PENELITIAN}

Penelitian ini menggunakan data sekunder yang diperoleh dari perusahaan manufaktur yang go-public di Indonesia. Bursa Efek Indonesia, Indonesia Capital Market Directory. Data sekunder yang digunakan adalah laporan keuangan tahunan yang dikeluarkan oleh perusahaan yang bersangkutan dari periode 2011-2014.

Populasi dalam penelitian ini adalah seluruh perusahaan manufaktur yang terdaftar di BEI selama periode 2011-2014 yang berjumlah 151 perusahaan. Alasan penggunaan perusahaan manufaktur karena perusahaan yang bergerak dalam bidang infrastruktur, utilitas, transportasi, perdagangan, dan jasa sangat terikat dengan peraturan pemerintah. Pengambilan sampel didasarkan pada metode purposive sampling dengan kriteria sebagai berikut:

\section{Tabel 1. Kriteria Sampling}

\begin{tabular}{clc}
\hline No. & \multicolumn{1}{c}{ Kriteria } & \multicolumn{1}{c}{ Jumlah } \\
\hline 1. & $\begin{array}{l}\text { Perusahaan manufaktur selama periode pengamatan } \\
\text { 2011-2014 }\end{array}$ & 151 \\
2. & $\begin{array}{l}\text { Perusahaan yang tidak listing selama berturut-turut di } \\
\text { BEI }\end{array}$ & $(7)$ \\
3. & $\begin{array}{l}\text { Perusahaan memiliki laba negatif } \\
\text { 4. }\end{array}$ & $(40)$ \\
5. Perusahaan memiliki nilai ekuitas negatif & $(33)$ \\
& $\begin{array}{l}\text { Perusahaan tidak melaporkan laporan keuangan dalam } \\
\text { bentuk rupiah }\end{array}$ & $(31)$ \\
\hline & Jumlah akhir sampel penelitian & $\mathbf{4 0}$ \\
\hline
\end{tabular}

Sumber data: ICMD

Sampel memenuhi uji normalitas jika jumlah minimum analisis penelitian multivariate adalah $\geq 30$. Pada penelitian ini digunakan pooled data (gabungan dari metode cross sectional dan time series).Variabel dependen dalam penelitian ini adalah harga saham, sedangkan variabel independen dalam penelitian ini adalah sebagai berikut:

(Laba) X1 $\quad=\frac{\text { Laba Tahunan }}{\text { Jumlah lembar saham yang beredar }}$

(Arus Kas Operasi) X2 $=\frac{\text { Arus Kas Operasi }}{\text { Jumlah lembar saham yang beredar }}$

(Nilai Buku Ekuitas) X3 $=\frac{\text { Total Ekuitas }}{\text { Jumlah lembar saham yang beredar }}$

Data penelitian dianalisis dengan menggunakan metode regresi linear berganda melalui program Statistical Package for Social Sciences ( SPSS ) versi 16. Analisis regresi linier berganda digunakan untuk melihat pengaruh dua variable bebas atau lebih terhadap variable terikat secara bersama-sama. Analisis dilakukan menggunakan uji regresi linier berganda dengan $\alpha=5 \%$. Pada pengujian regresi ini sebelumnya digunakan dua model terpisah. yaitu model pertama dilakukan dengan menggunakan laba, arus kas operasi dan nilai buku ekuitas sebagai variable bebas.Berdasarkan analisis yang telah dijelaskan sebelumnya maka dilakukan pengujian dengan persamaan sebagai berikut:

$$
Y=a+b_{1} X_{1}+\ldots+b_{n} X_{n}+e_{i}(\text { Gujarati, 1997: 24) }
$$

Penelitian ini menggunakan analisis linier berganda. Analisis regresi berganda merupakan teknik analisis statistika yang bertujuan untuk mengetahui hubungan antara 
variabel dependen dan variabel independen. Pada analisis regresi linear berganda terdapat 5 asumsi yang harus terpenuhi, diantaranya yaitu: asumsi linearitas, asumsi normalitas, asumsi multikolinieritas, asumsi autokorelasi dan asumsi heterokedastisitas.

\section{HASIL PENELITIAN DAN PEMBAHASAN}

Dalam penelitian yang bertindak sebagai variabel dependen adalah harga saham dan variabel independen adalah laba, arus kas operasi dan nilai buku ekuitas. Berdasarkan hasil olah data menggunakan alat bantu SPSS, diketahui bahwa harga saham, laba, arus kas operasi dan nilai buku ekuitas berdistribusi normal dengan standar deviasi sebesar 0.991.

Asumsi linearitas terpenuhi berdasarkan persamaan regresi yang terbentuk dalam penelitian ini yaitu:

Harga saham $=$ Konstanta + b1 Laba + b2Arus Kas Operasi + b3 Nilai Buku Ekuitas $+e$

Kenaikan harga saham diiringi dengan kenaikan variabel independen: laba, arus kas operasi dan nilai buku ekuitas.

Uji normalitas dilakukan untuk menguji apakah dalam model regresi, variable pengganggu atau residual memiliki distribusi normal atau tidak.Suatu model regresi yang baik adalah dimana datanya memiliki distribusi yang normal atau mendekati normal, distribusi normal akan membentuk garis lurus. Berdasarkan hasil uji normalitas dengan menggunakan alat bantu SPSS diketahui bahwa titik-titik menyebar disekitar garis lurus diagonal, maka dapat dikatakan bahwa data penelitian ini memiliki distribusi yang mendekati normal.

Uji Multikolinearitas dilakukan untuk menguji apakah data yang diolah tidak terdapat adanya multikolinearitas. Hal ini ditunjukkan dengan adanya nilai VIF sebesar 2.657 untuk variabel laba, 7.358 untuk variabel arus kas operasi, dan nilai buku ekuitas sebesar 6.264. Nilai VIF untuk semua variabel antara 1 sampai dengan 10 menunjukkan bahwa asumsi multikolinearitas terpenuhi.

Uji Autokorelasi dilakukan untuk mengetahui adanya autokorelasi yang menggunakan uji Durbin- watson yang bisa dilihat dari hasil penelitian regresi berganda. Hasil dari penelitian menunjukkan bahwa DW yang diperoleh adalah 1,839. Jadi dapat disimpulkan bahwa tidak terdapat autokorelasi.

Uji Heteroskedastisitas bertujuan untuk menguji apakah dalam model regresi terjadi ketidaksamaan variance dari residual satu observasi yang lain. Heteroskesdastisitas menggambarkan nilai hubungan antara nilai yang diprediksi dengan Studentized Delete Residual nilai tersebut.Model regresi yang baik adalah yang homoskedasitas atau tidak terjadi heterokesdasitas. Untuk mengetahui ada tidaknya multikolinearitas dapat dilihat dari nilai VIF (Variance Inflation Factor). Jika nilai VIF lebih besar dari 10 maka asumsi multikolinearitas tidak terpenuhi. Adanya tidaknya autokorelasi dianalisis dengan uji Durbinwatson.

Hasil analisis regresi dapat menjelaskan bagaimana bentuk pengaruh dari setiap variabel independen pada variabel dependen. Persamaan regresi disajikan pada tabel berikut :

Tabel 2. Koefisien Regresi dari Laba, Arus Kas Operasi dan Nilai buku ekuitas

\begin{tabular}{llllc}
\hline Variabel & Koefisien Regresi & Standar Error & $\mathrm{t}$ & $\begin{array}{l}\text { Nilai } \\
\text { Signifikan }\end{array}$ \\
\hline Konstanta & 2.338 & 0.362 & 6.457 & 0.000 \\
\hline Laba & 0.092 & 0.047 & 1.982 & $0.049^{*}$ \\
\hline Arus Kas Operasi & 0.854 & 0.083 & 10.328 & $0.000^{*}$ \\
\hline Nilai buku ekuitas & 0.071 & 0.098 & 0.729 & 0.467 \\
\hline * signifikan pada taraf nyata 5\% & & & \\
\hline \multicolumn{2}{l}{ Sumber: Data Primer diolah, 2016 } & & &
\end{tabular}


Sehingga model regresi yang terbentuk :

\section{Harga Saham $=2.338+0.092$ Laba +0.854 Arus Kas Operasi + 0.071nilai Buku Ekuitas + E}

Persamaan tersebut menunjukkan bahwa variabel laba,arus kas operasiberpengaruh signifikan terhadap harga saham sedangkan variabel nilai buku ekuitas tidak berpengaruh signifikan terhadap harga saham. Intepretasi dari persamaan regresi di atas adalah sebagai berikut:

1. Konstanta, $\alpha=2,338$. Nilai konstanta sebesar 2,338 menyatakan jika ada peningkatan laba, arus kas operasi dan nilai buku ekuitas, maka skor harga saham akan mengalami peningkatan sebesar 2,338.

2. Koefisisen regresi laba, $\beta_{1}=0,092$. Nilai koefisien laba sebesar 0,092 menyatakan jika terjadi peningkatan laba sebesar satu satuan maka harga saham akan mengalami peningkatan sebesar 0,092 satuan.

3. Koefisien regresi arus kas koperasi, $\beta_{2}=0,854$. Nilai koefisien arus kas operasi sebesar 0.854 menyatakan jika terjadi peningkatan arus kas operasi sebesar satu satuan maka harga saham akan mengalami peningkatan sebesar 0,854 satuan.

4. Koefisien regresi nilai buku ekuitas, $\beta_{3}=0,071$. Nilai buku ekuitas memiliki pengaruh yang tidak signifikan terhadap harga saham, jika terjadi peningkatan maupun penurunan pada variabel nilai buku ekuitas tidak berpengaruh terhadap harga saham.

Dari hasil analisis data menunjukkan bahwa variabel laba sebesar mempunyai sig. 0.049 yang lebih kecil dari taraf signifikansi yang ditentukan yakni 0.05. Nilai sig. untuk variabel laba lebih kecil dari taraf sig. 0.05. Maka dilihat dari hasil analisis diperoleh bahwa pengujian pertama yang menyatakan bahwa laba berpengaruh signifikan terhadap harga saham. Untuk variabel arus kas operasi yang mempunyai sig. 0.000. Besarnya nilai sig dari variabel arus kas operasi ini nilainya lebih kecil apabila dibandingkan dengan taraf signifikansi 5\%. Sehingga dapat diambil kesimpulan bahwa variabel arus kas operasi berpengaruh signifikan terhadap harga saham perusahaan. Maka dari itu, hasil pengujian yang menyatakan bahwa arus kas operasi berpengaruh signifikan terhadap harga saham perusahaan. Untuk variabel nilai buku ekuitas yang mempunyai sig. 0,467. Besarnya nilai signifikansi dari nilai buku ekuitas lebih besar dari 0,05. Besarnya thitung diperoleh sebesar $\mathrm{t}$ hitung $0,729<\mathrm{t}$ tabel 1,967. Maka dilihat dari hasil pengujian diperoleh bahwa nilai buku ekuitas tidak berpengaruh signifikan pada harga saham. Berdasarkan tabel diketahui bahwa pengaruh nilai buku ekuitas terhadap harga saham tidak signifikan sehingga jika ada peningkatan atau penurunan pada nilai buku harga saham tidak mengalami perubahan.

Nilai R-sq diperoleh sebesar 0.870 , artinya besarnya keragaman harga saham yang dapat dijelaskan oleh laba, arus kas operasi dan nilai buku ekuitas. Sedangkan nilai variabel lain tidak dijelaskan dalam penelitian ini nilainya kecil.Untuk variabel aruskasoperasi yang mempunyai nilai signifikan 0.000. dimana nilainya lebih kecil dibandingkan dengan taraf nyata 5\%. Sehingga dapat diambil kesimpulan bahwa variable arus kas operas iberpengaruh terhadap harga saham sehingga perusahaan menyatakan arus kas operasi berpengaruh signifikan terhadap harga saham. Pengujian koefisisen determinasi $\left(\mathrm{R}^{2}\right)$ bertujuan untuk menunjukkan besarnya derajat kemampuannya yang menerangkan variabel bebas terhadap variabel terikat dari fungsi tersebut. Nilai koefisien determinasi dari variabel independen sebesar 0.870 Berarti variabel independen dalam penelitian ini mampu menjelaskan varians harga saham perusahaan sebesar $87 \%$ dimana selebihnya yaitu $13 \%$ dijelaskan oleh faktor faktor diluar variabel tersebut.

\section{PEMBAHASAN}

Perusahaan- perusahaan yang terdaftar di Bursa Efek Indonesia disusun berdasarkan industri dan bagian-bagiannya sesuai dengan bisnis masing-masing perusahaan. Perusahaan yang listing di BEI digolongkan menjadi beberapa golongan. Penelitian ini dilakukan dengan 
mengambil populasi perusahaan manufaktur yang terdaftar di Bursa Efek Indonesia yang diperoleh dari Indonesian Capital Market Directory (ICMD). Diantara semua industri yang terdaftar di BEI, perusahaan-perusahaan yang termasuk dalam industri manufaktur mempunyai kelompok industri dengan jumlah total sebanyak 151 perusahaan dan jumlah populasi sebanyak 40 perusahaan dengan periode pengamatan dari tahun 2011 sampai tahun 2014. Industri manufaktur adalah subsektor industri yang paling dominan dan merupakan subsektor industri yang memberi kontribusi nilai tambah sangat besar terhadap sektor industri di Indonesia. Industri manufaktur merupakan sektor yang perlu mendapatkan perhatian berkenaan dengan dimensi lokasi dan keuntungan komparatifnya. Industri manufaktur mampu memberikan nilai tambah yang paling besar terhadap Produk Domestik Bruto (PDB) Indonesia (www.arvie-13.com).

Memasuki tahun 2014, optimisme kalangan industri manufaktur masih cukup besar walaupun sektor ini menghadapi tantangan yang cukup berat yaitu kenaikan bahan bakar minyak (BBM) dan tarif dasar listrik yang banyak menentukan daya saing hasil industri baik di pasar domestik maupun pasar ekspor. Keadaan ekonomi negara maju terutama Eropa yang masih terkena krisis finansial juga menjadi ancaman tambahan bagi pertumbuhan sektor ini. Namun potensi industri manufaktur untuk bisa berkembang pesat pada tahun 2014 masih cukup besar. Sektor industri yang utama di Indonesia seperti sektor otomotif, industri makanan dan minuman, industri elektronik, tekstil, dan banyak industri pengolahan lainnya mampu mempertahankan tingkat pertumbuhan yang tinggi (www.datacon.co.id). Pertumbuhan industri manufaktur selalu mengalami kenaikan dari tahun ke tahun. Pertumbuhan produksi industri manufaktur besar dan sedang tahunan pada tahun 2014 mengalami kenaikan sebesar 4,12\%. Produksi industri manufaktur pada tahun 2012 mengalami kenaikan sebesar 5,56\% dari tahun 2011. Produksi industri manufaktur tahun 2012 naik sebesar 4,45\% dari tahun 2011. Produksi industri manufaktur tahun 2012 naik sebesar 1,34\% dari tahun 2011 (www.bps.go.id). Persaingan industri manufaktur menuntut perusahaan untuk dapat lebih berkompetitif agar tidak terjebak dalam kemerosotan persaingan tersebut.

Perusahaan manufaktur lebih membutuhkan sumber dana jangka panjang untuk membiayai operasi perusahaan mereka salah satunya dengan investasi saham. Pasar modal menyediakan fasilitas untuk meyalurkan dana dari pihak yang kelebihan dana (lender) ke pihak yang memerlukan dana (borrower). Dengan menginvestasikan kelebihan dana yang dimiliki, lender mengharapkan dapat memperoleh imbalan dari penyerahan dana tersebut. Borrower mengharapkan dapat memperoleh dana untuk investasi tanpa harus menunggu dana dari hasil operasi laba. peranan utama pasar modal adalah pengalokasian kepemilikan modal saham secara ekonomis.

Dalam permasalahan yang umum, idealnya adalah pasar dimana harga memberikan isyarat yang akurat untuk pengalokasian modal. Hal itu berarti bahwa pasar dimana perusahaan dapat membuat keputusan investasi secara produktif dan investor dapat memilih di antara surat berharga yang mewakili kepemilikan atas aktivitas perusahaan di bawah asumsi harga surat berharga pada setiap saat mencerminkan secara penuh seluruh informasi yang tersedia. Pasar modal memiliki peran penting bagi perekonomian suatu negara karena pasar modal menjalankan dua fungsi, yaitu sebagai sarana bagi pendanaan usaha atau sebagai sarana bagi perusahaan untuk mendapatkan dari masyarakat pemodal (investor).

Dana yang diperoleh dari pasar modal dapat digunakan untuk pengembangan usaha, ekspansi, penambahan modal kerja, dan lain-lain. Kedua, pasar modal menjadi sarana bagi masyarakat untuk berinvestasi pada instrumen keuangan seperti saham, obligasi, reksa dana, dan lain-lain. Dengan demikian, masyarakat dapat menempatkan dana yang dimilikinya sesuai dengan karakteristik keuntungan dan risiko masing-masing instrumen (www.idx.co.id). Sedangkan harga saham juga berpengaruh terhadap pasar saham. Harga 
pasar (market price) adalah harga yang sedang berlaku di pasar. Nilai pasar saham adalah harga suatu saham pada pasar yang sedang berlangsung di bursa efek. Apabila bursa efek telah tutup maka harga pasar adalah harga penutupannya (clossing price). Untuk mendapatkan jumlah nilai pasar (market value) suatu saham yaitu dengan mengalikan harga pasar dengan jumlah saham yang dikeluarkan. Biasanya pergerakan harga saham disajikan setiap hari, berdasarkan harga penutupan di bursa pada hari tersebut.

Harga pasar saham akan selalu mengalami fluktuasi dan akan dipublikasikan kepada publik agar investor dan pihak-pihak lainnya yang berkepentingan dengan harga pasar saham dapat mengetahuinya untuk dijadikan bahan evaluasi dalam pengambilan keputusan masing-masing, harga pasar saham tersebut biasanya dipublikasikan dalam media masa. Harga saham adalah nilai bukti penyertaan modal pada perseroan terbatas yang telah listed di bursa efek, dimana saham tersebut telah beredar (outstanding securities)" (Fathul,2009).

Harga yang terbentuk dari kekuatan permintaan dan penawaran yaitu harga saham penutupan (closing price) pada tanggal pengumuman laporan keuangan. Indikator yang digunakan dalam penelitian ini adalah harga saham penutupan pada tanggal pengumuman laporan keuangan. Harga saham suatu perusahaan selalu mengalami pergerakan naik atau turun. Pergerakan pada harga saham inilah yang dapat memberikan keuntungan bagi para investor. Oleh karena itu para investor sangat membutuhkan informasi mengenai faktorfaktor yang dapat mempengaruhi harga saham baik secara langsung maupun tidak. Informasi yang didapat bisa berasal dari eksternal maupun internal perusahaan.

Dari eksternal perusahaan berhubungan dengan kondisi perekonomian, kebijakan pemerintah, dan tingkat suku bunga. Sedangkan dari internal perusahaan berhubungan dengan laporan keuangan dari perusahaan. Naik turunnya harga saham yang diperdagangkan di lantai bursa ditentukan oleh kekuatan pasar. Jika pasar menilai bahwa perusahaan penerbit saham dalam kondisi baik, maka harga saham perusahaan yang bersangkutan akan naik, demikian juga sebaliknya, jika perusahaan dinilai rendah oleh pasar maka harga pasar perusahaan juga akan ikut turun bahkan bisa lebih rendah dari harga pasar di pasar perdana. Dengan demikian, kekuatan tawar menawar di pasar sekunder antara investor yang satu dengan investor yang lain sangat menentukan harga saham perusahaan.

Salah satu cerminan dari pengharapan investasi terhadap nilai ekonomis perusahaan di masa mendatang adalah harga saham. Dengan dinamisnya harga saham maka untuk memilih suatu saham perlu dilakukan analisa yang mendalam terhadap berbagai faktor yang akan dapat mempengaruhi perusahaan dalam pencapaian nilai ekonominya. Analisis fundamental merupakan salah satu pendekatan dalam menganalisis saham. Data yang digunakan dalam pendekatan ini dapat berasal dari dalam perusahaan (analisa kondisi spesifik perusahaan), data - data industri (analisa industri), maupun data ekonomi (analisa ekonomi) yang akan mempengaruhi harga saham.

Analisis fundamental atau analisis perusahaan adalah analisis untuk menghitung nilai instrinsik saham dengan menggunakan data keuangan perusahaan (Jogiyanto, 2009). Analisis fundamental lebih menekankan pada kinerja internal perusahaan. Keyakinan bahwa informasi yang disampaikan oleh manajemen perusahaan dapat direspon secara positif oleh investor maupun calon investor. Dalam keseimbangan, harga pasar sekarang sekuritas merefleksikan rata-rata dari estimasi nilai instrinsik yang dibuat oleh investor. Investor yang perkiraan nilai instrinsiknya berbeda dari harga pasar efeknya adalah adanya perbedaan dengan konsesnsus pasar terhadap estimasi mereka baik expected returnnya ataupun risiko atau keduanya. Investor yang melakukan analisa fundamental yang baik memiliki perbedaan seharusnya dapat mengambil keunntungan dengan melakukan tindakan sebelum konsesnsus pasar menggambarkan informasi yang benar. Analisis perusahaan dilakukan para analis keuangan dan penanam modal dengan pemeriksaan pada berbagai aspek kinerja keuangan perusahaan 
untuk mengetahui kondisi dan prestasi keuangan perusahaan. Analisis terhadap laporan keuangan perusahaan dilakukan dengan maksud untuk memperoleh informasi dari laporan tersebut sehingga investor dapat membuat keputusan yang tepat pada saat akan menginvestasikan sejumlah dananya.

Sebelum membuat keputusan investasi, akan lebih menguntungkan jika investor melihat terlebih dahulu kinerja perusahaan melalui laporan keuangannya. Suatu alat yang sering digunakan selama pemeriksaan kinerja perusahaan tersebut adalah rasio keuangan, atau indeks yang berkaitan dengan dua buah data keuangan atau untuk mengetahui "mutu" suatu saham, calon investor perlu menggunakan faktor rasional. Faktor rasional disini berkaitan dengan analisis fundamental. Analisis teknikal merupakan upaya untuk memperkirakan harga saham (kondisi pasar) dengan mengamati perubahan harga saham tersebut (kondisi pasar) di waktu yang lalu (Husnan, 2005). Analisis teknikal ini kadangkala disebut market atau internal analysis karena menggunakan catatan dari market untuk memprediksi demand atau supply, saham atau pasar secara keseluruhan.

Analisis teknikal berdasarkan pada data pasar yang telah dipublikasikan yang merupakan kebalikan dari data analisa fundamental seperti earning, sales, growth rate, ataupun peraturan pemerintah. Untuk data pasar ini antara lain harga saham atau level dari indeks pasar, volume (jumlah dari saham yang diperjualbelikan) dan indikator teknikal seperti rasio bunga dan sebagainya. Pada analisis teknikal proses harga disesuaikan dengan informasi baru, hal tersebut merupakan penyesuaian yang bertahap menuju keseimbangan harga baru. Seperti penyesuaian dari level keseimbangan yang lama ke level yang baru, harga cenderung bergerak dalam trend sehingga harga saham dapat dikatakan menunjukkan trend yang dapat diidentifikasi yang dapat dieksploitasi oleh investor. Para investor ini mengidentifikasi arah perubahan saham ini kemudian mengambil posisi yang mendapatkan keuntungan dari trend. Analisis teknikal dapat diaplikasikan yaitu pada harga secara agregate (semua rata-rata industri) ataupun saham secara individual. Analisa teknikal ini meliputi penggunaan grafik, peraturan teknikal trading atau beberapa indikator perdagangan saham dalam bursa, seperti harga dan volume perdagangan. Harga dan volume adalah peralatan yang utama dari analisa teknikal, dan grafik adalah mekanisme terpenting untuk menunjukkan suatu informasi.

Dalam dunia usaha kita akan melihat kekuatan demand dan supply merupakan hasil dari perilaku harga, dan yang terpenting adalah trend atau semua arah dari harga. Dengan menggunakan grafik maka trend dapat diidentifikasi sebagai pola dari harga sahan yang memberikan signal dari perdagangan. Data tentang volume digunakan untuk mengukur kondisi secara umum dari pasar dan untuk membantu memprediksi trend. Bukti menunjukkan bahwa peningkatan/ penurunan harga biasanya berhubungan dengan peningkatan atau penurunan volume. Jika harga saham meningkat tapi aktivitas volume tidaklah berubah, maka para ahli teknikal menjadi skeptis tentang kecenderungan naiknya trend. Sedangkan pergerakan menurun dari beberapa pola, disertai dengan volume yang banyak maka mengindikasikan kondisi bearish, sebaliknya pergerakan harga saham yang naik disertai dengan volume perdagangan yang cukup besar mengindikasikan kondisi bullish.

Deskripsi variabel laba, arus kas operasi, nilai buku ekuitas terhadap harga saham pada perusahaan manufaktur di Bursa Efek Indonesia menghasilkan informasi yang menarik. Berdasarkan rata-rata laba, dapat diketahui bahwa rata-rata laba menunjukkan pengaruh yang signifikan dari tahun ke tahun. Berdasarkan nilai buku ekuitas, dapat diketahui bahwa nilai buku ekuitas tidak berpengaruh signifikan dari tahun 2011- 2014. Berdasarkan arus kas operasi, dapat diketahui bahwa arus kas operasi menunjukkan pengaruh yang signifikan dari tahun 2011-2014. Selanjutnya berdasarkan harga saham, dapat diketahui bahwa nilai harga saham menunjukkan trend peningkatan dari tahun ke tahun. Pembahasan di atas sudah dijelaskan tentang deskripsi variabel-variabel penelitian.. Hasil asumsi klasik yang dilakukan 
juga menunjukkan hasil yang baik. Berdasarkan gambar grafik yang diperoleh, data menunjukkan normalitas yang baik dengan ditandai sebaran titik-titik yang berada di sekitar garis diagonal. Selain itu data yang diperoleh menunjukkan heteroskedastisitas yang baik didasarkan pada titik-titik yang menyebar merata pada grafik plot reliabilitas.

Setelah diketahui bahwa data yang digunakan semuanya memenuhi syarat untuk melakukan analisis regresi, setelah dilakukan pengujian regresi maka pada bagian di bawah ini akan disajikan pembahasan dari hasil analisis yang dilakukan.

\section{Pengaruh Laba terhadap Harga saham}

Penelitian ini berhasil membuktikan adanya pengaruh positif informasi laba terhadap harga saham. Data diatas menunjukkan bahwa untuk variabel laba yang mempunyai sig. 0.049 lebih kecil dari taraf signifikansi yang ditentukan yakni 0.05. Nilai sig. untuk variabel laba lebih kecil dari taraf sig. 0.05. Maka dilihat dari hasil analisis diperoleh bahwa pengujian pertama yang menyatakan bahwa laba berpengaruh signifikan terhadap harga saham.Berdasarkan Tabel 2 diketahui bahwa koefisien regresi untuk laba sebesar 0.092. Hal ini menunjukkan bahwa setiap kenaikan laba sebesar $1 \%$ akan meningkatkan harga saham sebesar 9.2\%. Hasil ini mendukung hasil penelitian Triyono dan Hartono dan Ferry dan Wati (2004) yang juga menemukan fakta yang sama, yaitu ditemukannya pengaruh signifikan informasi laba terhadap harga saham.Hasil pengujian dengan menggunakanmodel regresi semuanya menunjukkan hasil yang konsisten, dimana informasi mengenai laba berpengaruh terhadap harga saham.

Hubungan positif antara laba dengan harga saham dapat diartikan bahwa semakin tinggi nilai laba akan menimbulkan reaksi positif dari pasar. Hubungan yang positif ini dapat diartikan bahwa investor merespon positif terhadap perkembangan nilai laba karena perusahaan yang memiliki kemampuan untuk meningkatkan laba, cenderung harga sahamnya juga akan meningkat. Maksudnya jika perusahaan memperoleh laba yang semakin besar, maka perusahaan akan mampu membagikan dividen yang semakin besar dan menghasilkan return saham yang tercermin dalam nilai saham perusahaan tersebut. Hal ini sesuai dengan pendapat Wetson dan Brigham (2001) semakin tinggi laba per lembar saham yang diberikan perusahaan akan memberikan pengembalian yang cukup baik. Ini akan mendorong investor untuk melakukan investasi yang lebih besar lagi sehingga harga saham perusahaan akan meningkat

Laba yang dihasilkan oleh perusahaan manufaktur tersebut akan mempengaruhi ekspektasi para investor untuk memperoleh pembagian laba dalam bentuk dividen. Selanjutnya ekspektasi tersebut akan mempengaruhi perilaku investor dalam melakukan transaksi di bursa. Investor akan menahan dan membeli saham-saham perusahaan yang mampu menghasilkan dan meningkatkan labanya setiap tahun. Apabila semua investor berperilaku yang sama maka terjadi kelebihan permintaan dari penawaran saham yang bersangkutan. Sehingga pada akhirnya keadaan ini akan mendorong naiknya harga saham. Laba terbagi ke dalam empat kelompok, yaitu laba bersih perusahaan dan laba bersih bagi investor, laba bersih bagi pemegang saham dan laba bersih bagi pemegang ekuias. Laba tahunan memiliki kandungan informasi, apabila pengumuman laba akan menyebabkan perubahan reaksi investor terhadap distribusi aliran kas di masa yang akan datang, yang akan menyebabkan perubahan harga saham. Perubahan harga saham di sekitar tanggal pengumuman diharapkan lebih besar jika dibandingkan dengan perubahan harga saham di luar tanggal pengumuman. Koefisien laba lebih tinggi dibandingkan arus kas operasi dan nilai buku ekuitas. Hal ini berarti bahwa pengaruh nilai laba lebih tinggi dibandingkan nilai buku ekuitas dan arus kas operasi, sehingga pada saat perusahaan mengalami laba maka investor menggunakan informasi laba untuk menilai perusahaan tersebut. Berdasarkan hasil penelitian ini dapat disimpulkan bahwa secara parsial laba dapat memberikan informasi yang relevan bagi investor sebagai dasar pertimbangan keputusan berinvestasi. 
Laba dalam laporan keuangan merupakan salah satu parameter kinerja perusahaan yang mendapat perhatian utama dari investor. Laba memiliki manfaat untuk menilai kinerja manajemen, membantu mengestimasi kemampuan laba yang representatif dalam jangka panjang, memprediksi laba dan menaksir risiko dalam investasi atau kredit.Laba hanya salah satu informasi akuntansi yang memiliki keterbatasan untuk mengungkapkan informasi yang dibutuhkan oleh investor. Tujuan utama penyajian laba adalah menyediakan informasi yang berguna bagi mereka yang berkepentingan dengan laporan keuangan. Apa yang perlu diperhitungkan dalam laba, tergantung tujuan yang ingin dicapai dari penyaji. Laba sering digunakan sebagai suatu dasar untuk pengenaan pajak, kebijakan deviden, pedoman investasi serta pengambilan keputusan dan unsur prediksi. Pengukuran laba bukan saja penting untuk menentukan prestasi perusahaan tetapi penting juga penting sebagai informasi bagi pembagian laba dan penentuan kebijakan investasi. Oleh karena itu, laba menjadi informasi yang dilihat oleh banyak seperti profesi akuntansi, pengusaha, analis keuangan, pemegang saham, ekonom, fiskus, dan sebagainya.

Informasi laba hanya salah satu informasi akuntansi yang memiliki keterbatasan untuk mengungkapkan informasi yang dibutuhkan oleh investor. Tujuan utama penyajian laba adalah menyediakan informasi yang berguna bagi mereka yang berkepentingan dengan laporan keuangan. Apa yang perlu diperhitungkan dalam laba, tergantung tujuan yang ingin dicapai dari penyajian laba akuntansi itu sendiri. Secara garis besar ada dua konsep untuk menghitung laba (Hendriksen dan Breda, 2000) yaitu: pertama; Konsep laba operasi kini (current operating concept), dimana konsep ini memusatkan pada pengukuran efisiensi perusahaan bisnis. Dalam menghitung laba penekanan tertentu diletakkan pada istilah kini (masa berjalan) dan operasi. Hanya perubahan nilai dan kejadian yang dapat dikendalikan oleh manajemen dan yang dihasilkan dari periode berjalan yang harus dimasukkan. Kedua; Konsep laba komprehensif (all-inclusive), merupakan total perubahan dalam modal yang diakui dengan mencatat transaksi atau revaluasi perusahaan selama suatu periode tertentu, kecuali untuk pembagian dividen dan transaksi modal. Jika dilihat dari pendekatan kepemilikan, laba bersih biasanya diasumsikan sebagai penghasilan bersih atau laba bersih yang terutang kepada pemegang saham atau pemilik saat ini dari perusahaan tersebut. Akan tetapi terdapat beberapa alasan sah untuk penyajian angka laba bersih yang merupakan penghasilan bersih pada kelompok penerima yang lebih sempit atau lebih luas, diantaranya: Laba bersih perusahaan. Laba bersih pada perusahaan adalah suatu konsep dari laba bersih, sehingga beban bunga, pajak penghasilan, dan distribusi bagi hasil yang sebenarnya adalah bukan merupakan determinan dari laba bersih perusahaan. Laba bersih pada investor dalam konsep satuan usaha, laba kepada investor mencakup bunga atas utang, dividen pada pemegang saham preferen dan pemegang saham biasa, dan sisa yang tak dibagikan.

Hasil penelitian tersebut menunjukkan bahwa pada saat pengumuman laba, tingkat volume perdagangan saham meningkat dan hal ini akan berpengaruh pada harga saham. Hasil ini menyatakan bahwa investor seringkali mendasarkan keputusan investasinya pada tingkat laba dari perusahaan yang mencerminkan bagaimana kondisi perusahaan tersebut. Informasi yang terkandung dalam angka akuntansi berguna jika laba yang sesunguhnya berbeda dengan laba harapan investor maka pasar akan bereaksi yang tercermin dalam pergerakan harga saham sekitar tanggal pengumuman laba. Harga saham cenderung naik apabila laba yang dilaporkan lebih besar dari laba harapan, dan sebaliknya harga saham cenderung turun apabila laba yang dilaporkan lebih kecil dari laba harapan. Brown dalam Triyono dan Hartono (2000) melakukan penelitian mengenai dampak pengumuman laporan tahunan terhadap reaksi pasar modal. Hasil studinya menemukan bahwa laba bersih memiliki kandungan informasi yang relevan bagi investor yang menyebabkan perubahan terhadap harga saham.Hasil pengujian yang signifikan menunjukkan indikasi bahwa informasi 
mengenai laba perusahaan lebih banyak dipakai oleh investor dalam menilai kinerja perusahaan manufaktur di BEI.

\section{Pengaruh Arus Kas Operasi Terhadap Harga Saham}

Penelitian ini berhasil membuktikan adanya pengaruh arus kas operasi terhadap harga saham. variable arus kas operasi yang mempunyai nilai signifikan 0.000. dimana nilainya lebih kecil dibandingkan dengan taraf nyata 5\%. Sehingga dapat diambil kesimpulan bahwa variable arus kas operasi berpengaruh positif dan signifikan terhadap harga saham. Dari Tabel 2 diketahui bahwa koefisien regresi untuk variabel arus kas operasi sebesar 0.854. Nilai tersebut menunjukkan bahwa setiap kenaikan arus kas operasi sebesar $1 \%$ dapat meningkatkan harga saham sebesar $85.4 \%$. Laporan arus kas dapat memberi informasi mengenai likuiditas perusahaan, fleksibilitas keuangan perusahaan, dan kemampuan operasional perusahaan (M. Hanafi \& Abdul Halim, 2000). Dalam melakukan analisis investasi, investor seringkali menggunakan informasi dalam laporan arus kas yang lebih mencerminkan likuiditas daripada informasi laba. Analisis mengenai pengaruh publikasi laporan arus kas terhadap volume perdagangan saham di pasar modal. Secara umum laporan arus kas dapat memberikan pengaruh yang signifikan terhadap volume perdagangan saham. Penelitian tersebut menghasilkan adanya hubungan positif antara arus kas dari aktivitas operasi (AkOp) dan antara arus kas dari aktivitas Investasi (AkIn) terhadap volume perdagangan saham. Sedangkan antara arus kas dari aktivitas pendanaan (AkDa) menunjukkan hubungan yang negatif terhadap volume perdagangan saham.

Arus kas dari operasi merupakan arus kas yang berasal dari transaksi yang mempengaruhi laba bersih. Aktivitas operasi bisa menjadi indikator yang menentukan operasi perusahaan untuk dapat menghasilkan arus kas yang cukup untuk melunasi pinjaman, memelihara kemampuan operasi perusahaan, membayar dividen dan melakukan investasi baru tanpa mengandalkan pada sumber keuangan dari luar. Arus kas yang berasal dari aktivitas operasi dalam jangka panjang merupakan sumber pendanaan yang sangat menentukan kelangsungan hidup perusahaan. Jika suatu bisnis memiliki aliran kas negatif dari aktivitas operasi maka tidak akan dapat meningkatkan kas dari sumber potensial lain dalam jangka waktu yang tidak terbatas karena keterbatasan perusahaan dalam mengantisipasi peluang investasi yang ada. Hasil pengujian yang menghasilkan arah pengaruh positif signifikan signifikan menunjukkan indikasi bahwa informasi tentang aliran kas dari aktivitas operasi menjadi perhatian utama dari investor akan kinerja perusahaan di masa depan.

Arus kas dari aktivitas operasi dapat menjadi perhatian penting karena dalam jangka panjang untuk kelangsungan hidup perusahaan. Aktivitas operasi adalah aktivitas penghasil utama pendapatan perusahaan. Semakin tinggi kemampuan menghasilkan kas, diharapkan dapat meyakinkan investor bahwa operasi perusahaan dapat menghasilkan kas yang cukup untuk melunasi pinjaman, memelihara kemampuan operasi perusahaan, membayar dividend dan melakukan investasi baru tanpa mengandalkan pada sumber dari luar. Suatu bisnis harus menghasilkan arus kas bersih yang positif dari aktivitas operasi. Jika suatu bisnis memiliki arus kas negatif dari aktivitas operasi maka tidak akan dapat arus meningkatkan kas dari sumber lain dalam jangka waktu yang tidak terbatas. Livnat dan Zarrowin (1990) dengan model penilaian menunjukkan bahwa unexpected cash inflows or outflows dari operasi dalam perioda tertentu akan memperngaruhi harga saham melalui pengaruhnya pada arus kas, sehingga diharapkan komponen arus kas dari operasi mempunyai hubungan yang signifikan dengan return saham.

Hal ini mengindikasikan bahwa laporan arus kas operasi juga merupakan bagian yang tidak terpisahkan dari laporan keuangan untuk setiap periode penyajian pelaporan keuangan. Kandungan informasi laporan arus kas operasi dapat diukur dengan menggunakan kekuatan hubungan antara arus kas dengan harga saham atau return 
saham. Informasi laporan arus kas akan dikatakan mempunyai makna apabila digunakan sebagai dasar dalam pengambilan keputusan oleh investor. Apabila dengan dipublikasikan laporan arus kas menyebabkan investor pasar modal bereaksi melakukan pembelian atau penjualan saham yang selanjutnya tercermin dalam harga saham, berarti laporan arus kas mempunya kandungan informasi. Hastuti dan Sudibyo (1998) menemukan bukti bahwa pengumuman laporan arus kas mempengaruhi keputusan investor di pasar modal. Hal ini terefleksikan dalam rata-rata perubahan aktivitas volume perdagangan relatif di seputar tanggal publikasi laporan keuangan pada periode sebelum dan sesudah pelaporan arus kas. Ini dapat diartikan bahwa informasi yang terdapat dalam laporan arus kas mempengaruhi perdagangan saham di pasar modal. Suadi (1998) menyatakan bahwa laporan arus kas mempunyai hubungan dengan jumlah dividen yang terjadi dalam satu tahun setelah terbitnya laporan arus kas. Dengan demikian dapat dikatakan bahwa laporan arus kas mempunyai kandungan informasi dan bermanfaat bagi pemegang saham.

Penelitian ini berhasil membuktikan adanya pengaruh arus kas operasi terhadap harga saham.Hasil ini mendukung hasil penelitian Triyono dan Hartono (2000) dan Ferry dan Wati (2004). Arus kasoperasi merupakan arus kas yang berasal dari transaksi yang mempengaruhi laba bersih. Arus Kas operasi bisa menjadi indikator yang menentukan operasi perusahaan untuk dapat menghasilkan arus kas yang cukup untuk melunasi pinjaman, memelihara kemampuan operasi perusahaan, membayar dividen dan melakukan investasi baru tanpa mengandalkan pada sumber keuangan dari luar. Arus kas operasi dalam jangka panjang merupakan sumber pendanaan yang sangat menentukan kelangsungan hidup perusahaan. Jika suatu bisnis memiliki aliran kas negatif arus kas operasi maka tidak akan dapat meningkatkan kas dari sumber potensial lain dalam jangka waktu yang tidak terbatas karena keterbatasan perusahaan dalam mengantisipasi peluang investasi yang ada.

Hasil pengujian kedua yang menghasilkan arah pengaruh positif signifikan signifikan menunjukkan indikasi bahwa informasi tentang arus kas operasi menjadi perhatian utama dari investor akan kinerja perusahaan di masa depan, walaupun berdasarkan hasil pengujian sebelumnya menunjukkan bahwa informasi total arus kas dianggap tidak lagi informatif. Hasil ini juga mendukung hasil penelitian Triyono dan Jogiyanto (2000) yang menyimpulkan bahwa pemisahan total arus kas kedalam ketiga komponen arus kas, khususnya arus kas operasi, lebih berguna bagi investor. Arus kas dari aktivitas operasi dapat menjadi perhatian penting karena dalam jangka panjang untuk kelangsungan hidup perusahaan, suatu bisnis harus menghasilkan arus kas bersih yang positif dari aktivitas operasi. Jika suatu bisnis memiliki arus kas negatif dari aktivitas operasi maka tidak akan dapat meningkatkan kas dari sumber lain dalam jangka waktu yang tidak terbatas. Model penilaian menunjukkan bahwa unexpected cash inflows or outflows dari operasi dalam perioda tertentu akan memperngaruhi harga saham melalui pengaruhnya pada arus kas, sehingga diharapkan komponen arus kas dari operasi mempunyai hubungan yang signifikan dengan return saham. Ali (1994) dengan menggunakan pendekatan non-linier memberikan dukungan pada analisis bahwa arus kas dari operasi mempunyai kandungan informasi di luar laba.

Penelitian ini berhasil membuktikan adanya pengaruh arus kas operasi terhadap harga saham.Hasil ini mendukung hasil penelitian Triyono dan Hartono (2000) dan Ferry dan Wati (2004). Arus kasoperasi merupakan arus kas yang berasal dari transaksi yang mempengaruhi laba bersih. Arus Kas operasi bisa menjadi indikator yang menentukan operasi perusahaan untuk dapat menghasilkan arus kas yang cukup untuk melunasi pinjaman, memelihara kemampuan operasi perusahaan, membayar dividen dan melakukan investasi baru tanpa mengandalkan pada sumber keuangan dari luar. Arus kas operasi dalam jangka panjang merupakan sumber pendanaan yang sangat menentukan kelangsungan hidup perusahaan. Jika suatu bisnis memiliki aliran kas negatif arus kas operasi maka tidak akan dapat meningkatkan kas dari sumber potensial lain dalam jangka waktu yang tidak terbatas karena keterbatasan 
perusahaan dalam mengantisipasi peluang investasi yang ada. Arus kas operasi merupakan arus kas yang berasal dari transaksi yang mempengaruhi laba bersih. Arus Kas operasi bisa menjadi indikator yang menentukan operasi perusahaan untuk dapat menghasilkan arus kas yang cukup untuk melunasi pinjaman, memelihara kemampuan operasi perusahaan, membayar dividen dan melakukan investasi baru tanpa mengandalkan pada sumber keuangan dari luar. Arus kas operasi dalam jangka panjang merupakan sumber pendanaan yang sangat menentukan kelangsungan hidup perusahaan. Jika suatu bisnis memiliki aliran kas negatif arus kas operasi maka tidak akan dapat meningkatkan kas dari sumber potensial lain dalam jangka waktu yang tidak terbatas karena keterbatasan perusahaan dalam mengantisipasi peluang investasi.

\section{Pengaruh Nilai buku ekuitas Terhadap Harga Saham}

Hasil penelitian variabel nilai buku ekuitas tidak berpengaruh signifikan terhadap harga saham perusahaan. Variabel nilai buku ekuitas yang mempunyai nilai signifikan 0,467. Besarnya nilai signifikansi dari nilai buku ekuitas lebih besar dari 0,05. Besarnya t hitung diperoleh sebesar $\mathrm{t}$ hitung $0,729<\mathrm{t}$ tabel 1,967 , maka dilihat dari hasil pengujian diperoleh bahwa nilai buku ekuitas tidak berpengaruh signifikan pada harga saham.

Berdasarkan tabel 2 diketahui bahwa pengaruh nilai buku ekuitas terhadap harga saham tidak signifikan sehingga jika ada peningkatan atau penurunan pada nilai buku ekuitas maka harga saham tidak mengalami perubahan. Nilai buku memberikan informasi mengenai besarnya nilai dari sumber daya yang dimiliki perusahaan. Pada saat perusahaan mengalami keadaan financial distress, maka informasi nilai buku ekuitas menjadi lebih relevan dibandingkan informasi laba dalam menilai perusahaan. Hal ini disebabkan dalam kondisi tersebut, perusahaan akan mencari alternatif lain yang lebih baik dalam pengelolaan sumber daya yang dimiliki. Nilai buku (book value) dapat diartikan sebagai nilai saham menurut pembukuan perusahaan emiten.

Anggono dan Baridwan (2003), dalam penelitiannya, mengekspresikan nilai perusahaan sebagai fungsi laba dan nilai buku. Nilai buku saham merupakan menunjukkan aktiva bersih perusahaan yang dimiliki oleh pemegang saham dengan memiliki satu lembar saham. Aktiva bersih perusahaan adalah sama dengan total ekuitas pemegang saham, dan tentunya informasi mengenai nilai buku akan bermanfaat bagi investor sebagai pertimbangan untuk melakukan transaksi saham. Indra dan Syam (2004) menyatakan bahwa nilai buku merupakan pengganti atau wakil (proxy) untuk mendapatkan normal masa depan yang diharapkan (expected future normal earnings). Wild et. al dalam Suryani (2007), nilai buku per lembar saham adalah angka per lembar saham yang berasal dari likuidasi perusahaan pada jumlah yang dilaporkan dalam neraca.

Nilai buku merupakan hal yang perlu dan berguna karena dapat digunakan untuk mengetahui saham-saham mana yang bertumbuh (growth) dan yang murah (undervalued). Nilai buku saham sangat menentukan harga pasar saham yang bersangkutan. Oleh karena itu, sebelum investor memutuskan untuk membeli atau menjual saham, mereka harus memperhatikan nilai buku saham yang bersangkutan dan membandingkan dengan harga yang ditawarkan. Nilai buku per lembar saham merupakan aktiva bersih (net assets) yang dimiliki oleh pemegang saham dengan memiliki satu lembar saham. Karena aktiva bersih adalah sama dengan total ekuitas pemegang saham, maka nilai buku per lembar saham adalah total ekuitas dibagi dengan jumlah saham yang beredar menurut Jogiyanto (2009) Menurut Almilia dan Sulistyowati (2007), nilai buku merupakan ukuran neraca atau aset bersih yang menghasilkan laba. Nilai buku per lembar saham merupakan aktiva bersih (net assets) yang dimiliki oleh pemegang saham dengan memiliki satu lembar saham. Karena aktiva bersih adalah sama dengan total ekuitas pemegang saham, maka nilai buku per lembar saham adalah total ekuitas dibagi dengan jumlah saham yang beredar. 
Hasil penelitian menunjukkan bahwa nilai buku ekuitas tidak pengaruh signifikan terhadap harga saham. Nilai buku yang berasal dari neraca memberikan informasi tentang nilai bersih sumber daya perusahaan. Pada penelitian ini nilai buku ekuitas diukur oleh total ekuitas dibagi jumlah saham yang beredar. Perusahaan dengan pertumbuhan laba tinggi, sebagian besar penilaian ekuitas akan ditunjukkan oleh laba abnormal dan sebagian kecil ditunjukkan oleh nilai buku ekuitas. Peningkatan laba pada perusahaan tidak diikuti dengan kenaikan nilai buku ekuitas, nilai buku relatif stabil dari tahun ke tahun. Nilai ekuitas akan meningkat seiring dengan peningkatan laba bagi perusahaan-perusahaan yang mengalami pertumbuhan. Nilai perusahaan yang sedang mengalami pertumbuhan tercermin pada laba. Nilai buku ekuitas menunjukkan aktiva bersih (net asset) yang dimiliki oleh pemegang saham dengan memiliki satu lembar saham. Aktiva bersih adalah sama dengan total ekuitas pemegang saham, maka nilai buku per lembar saham adalah total ekuitas dibagi jumlah saham yang beredar.

Maka dari itu, pengujian ketiga yang menyatakan bahwa nilai buku ekuitas tidak berpengaruh signifikan terhadap harga saham perusahaan. Nilai buku ekuitas merupakan proksi yang lebih baik untuk memprediksi laba di masa mendatang terutama jika perusahaan mengalami kesulitan masalah keuangan. Hasil penelitian Almilia dan Sulistyowati (2007) menunjukkan bahwa koefisien penilaian dan kekuatan penjelas inkremental nilai buku ekuitas lebih tinggi pada saat perusahaan mengalami kesulitan keuangan. Hasil penelitian ini mendukung pernyataan Burgstahler dan Dichev dalam Almilia dan Sulistyowati (2007) yang menyatakan bahwa nilai buku ekuitas yang diperoleh dari neraca hanya memberikan informasi tentang nilai bersih sumber daya perusahaan, sehingga nilai buku ekuitas mempunyai nilai pengaruh yang jika aktivitas perusahaan mengalami keuntungan.

\section{E. PENUTUP}

Berdasarkan hasil dan pembahasan yang telah dikemukakan, maka dapat disimpulkan bahwa Laba memberikan informasi dan bermanfaat dalam penilaian sekuritas. Semakin besar labasuatu perusahaan maka kecenderungan yang ada adalah semakin tinggi harga saham. Hal ini terjadi karena laba perusahan pada akhirnya akan meningkatkan nilai perusahaan dan meningkatkan kekayaan pemegang saham dalam bentuk naiknya harga saham. Laba yang dihasilkan oleh perusahaan manufaktur tersebut akan mempengaruhi ekspektasi para investor untuk memperoleh pembagian laba dalam bentuk dividen.

Informasi arus kas operasi dimana nilai perusahaan berhubungan dengan kemampuan menghasilkan arus kas. Sehingga pada saat arus kas operasi meningkat maka nilai perusahaan akan naik, yang selanjutnya juga akan menaikkan harga saham. Investor menggunakan informasi arus kas operasi sebagai dasar pengambilan keputusan berinvestasi.

Nilai buku ekuitas tidak berpengaruh terhadap harga saham. Investor tidak menggunakan nilai buku ekuitas sebagai informasi yang perlu dipertimbangkan dalam pengambilan keputusan berinvestasi ketika aktivitas perusahaan mengalami keuntungan.

Pada penelitian ini untuk menentukan harga saham tidak hanya berasal dari faktor intern perusahaan saja tetapi juga dari ekstern perusahaan. Penelitian ini dapat dijadikan pedoman bagi investor dan calon investor dalam berinvestasi saham pada perusahaan manufaktur. Faktor internal dan eksternal perusahaan menjadi pertimbangan penting dalam mengambil keputusan untuk berinvestasi saham. Faktor tersebut juga dapat dijadikan pertimbangan bagi perusahaan dalam menentukan harga saham, karena faktor eksternal tidak dimasukkan dalam penelitian ini.

Berdasarkan hasil analisis dan pembahasan serta hasil kesimpulan penelitian, maka disarankan pada penelitian selanjutnya jika semua perusahaan yang terdaftar di BEI dapat dijadikan sampel penelitian. Hal ini akan dapat diketahui perbedaan mengenai karakteristik perusahaan pada sektor manufaktur dengan sektor lainnya yang berkaitan dengan variabel- 
variabel yang mempengaruhi saham. Selain itu diharapkan untuk menambah variabelvariabel fundamental maupun teknikal yang dianalisis pengaruhnya terhadap harga saham. Dengan adanya penambahan variabel diharapkan semakin banyak informasi yang digunakan dalam mempertimbangkan keputusan berinvestasi.

\section{DAFTAR PUSTAKA}

Adiwiratama, J. 2012. Pengaruh Informasi Laba, Arus Kas dan Size Perusahaan terhadap return Saham (Studi empiris pada perusahaan manufaktur yang terdaftar di BEI). JINAH (Jurnal Ilmiah Akuntansi dan Humanika), 2(1).

Amalia, Anissa. 2010. Analisis Relevansi Informasi Laba Akuntansi, Nilai buku ekuitas Ekuitas, dan Arus Kas dengan Harga Saham. Tesis tidak dipublikasikan. Jakarta: Universitas Budi Luhur.

Atwood, T.J., Drake, M.S. and Myers, L.A., 2010. Book-tax conformity, earnings persistence and the association between earnings and future cash flows. Journal of Accounting and Economics, 50(1), pp.111-125.

Anggono,Alexander dan Baridwan,Zaki. 2003. Pengaruh Kebijakan Pembagian Deviden, Kualitas Akrual, dan Ukuran Perusahaan pada Relevansi nilai dividen, nilai buku ekuitas, dan laba. Simposius nasional akuntansi VI, 393-403.

Arikunto, Suharsimi. 2010. Prosedur Penelitian (Suatu Pendekatan Praktik, edisirevisi). Jakarta: Rineka Cipta.

Ball, Ray, Philip Brown, 2005. An Empirical Evaluation of Accounting Income Number, Journal of Accounting Research 6 (Autumn) : 159-178.

Boucher, Christopher. 2006. Stock Prices Inflation Puzzle and the Predictability of Stock Market Returns. Economics Letters Volume 90: 205-212.

Brigham, E, F \& Wetson, J, F. 2005. Dasar-Dasar manajemen Keuangan, Edisi kesembilan, Jilid 2, Penerbit Erlangga, Jakarta.

Chkili, Walid, Chaker Aloui dan Duc Khuong Nguyenc. 2012. Asymmetric Effects andLong Memory in Dynamic Volatility Relationships Between Stock Returns andExchange Rates. International Financial Markets, Instrument and Money Volume $22: 738-757$.

Davis, A.K., Piger, J.M. and Sedor, L.M., 2012. Beyond the numbers: Measuring the information content of earnings press release language. Contemporary Accounting Research, 29(3), pp.845-868.

Ahmad, K. 2004. Dasar-dasar Manajemen Investasi dan Portofolio. PT. Rineka Cipta. Jakarta.

Aisjah, Siti. 2012. Strategi Diversifikasi Korporat dan Penciptaan Nilai Perusahaan. Malang Universitas Brawijaya Press.

Ghozali, Imam. 2006. Aplikasi Analisis Multivariat dengan Program SPSS, Cetakan ke 5, Badan Penerbit Undip, Semarang.

Fahmi, I. 2011. Analisis Laporan Keuangan.

Gantyowati, Evi. 2001. Hubungan Antara Operating Cash Flow dan Accrual dengan Return Saham. Kompak. No. 3. September: 275-298.

Gujarati, Damodar. 1997. Ekonometrika Dasar. Erlangga. Jakarta.

Gunawan dan Bandi. 2000. Analisis Kandungan Informasi Laporan Arus Kas. Makalah Simposium Nasional Akuntansi III. IAI-KAPd.

Hanafi, M. Hanafi dan Abdul Halim. 2005. Analisis Laporan Keuangan. Edisi Kedua. UPP. AMP. YKPN. Yogyakarta. 
Hadi, Kumala. 2004. The Effect of Growth And Debt Level on Market Value-Earnings and Book Value of Equity Relationship.The Journal of Accounting, Management, and Economics Research. Vol. 3, No. 2. September: 119-131.

Halim, A. 2005. Analisis Investasi. Salemba Empat. Jakarta.

Ho, Kin-Yip, Lin Zheng, Zhaoyong Zhang. 2012. Volume, Volatility andInformationLinkages in theStock and OptionMarkets. Review of Financial Economics, Volume 21, Issue 4, Pages 168-174.

Husnan, Suad. 2005. Dasar-dasar Teori Portofolio dan Analisis Sekuritas Edisi Ketiga. UPP AMP YKPN. Yogyakarta.

Hartono, Jogiyanto. 2003. Teori Portofolio dan Analisis Investasi. Edisi Ketiga. BPFE. Yogyakarta.

Indra.,Fazli Syam. 2004. Hubungan Laba, Nilai buku ekuitas, dan Total Arus Kas dengan Market Value: Studi Akuntansi Relevansi Nilai. MakalahSimposium Nasional Akuntansi VII. IAIKAPd

Iustian, Rio dan Arifah, D. Amalia. 2013. Analisis Pengaruh Informasi Laba, Nilai buku ekuitas Ekuitas, dan Arus Kas Operasi Terhadap Harga Saham. Jurnal Ekonomi, Vol 8 No 1, Juni 2013:17-27

Jogiyanto. 2009. Teori Portofolio dan Analisis Investasi. Edisi IV, Cetakan 1. BPFE. Yogyakarta. .

Jogiyanto. 2009. Konsep Aplikasi PLS (Partial Least Square) Untuk Peneltian Empiris. Yogyakarta: BPFE

Kwon, Gee-Jung. 2009, The Value Relevance of Book Values, Earnings and Cash Flows: Evidence from Korea. International Journal of Business Management, Volume 4, No. 40: $28-42$.

Lubis, Ade Fatma. 2008. Pasar Modal: Sebuah Pendekatan Pasar Modal Terintegrasi. Lembaga Penerbit Fakultas Ekonomi UI: Jakarta.

Luo, Mei. 2008. Unusual OperatingCash Flows and StockReturns. Journal of Accounting and Public Policy, Volume 27, Issue 5, Pages 420-429

Nwaeze, E.T., Yang, S.S. and Yin, Q.J., 2006. Accounting information and CEO compensation: The role of cash flow from operations in the presence of earnings. Contemporary Accounting Research, 23(1), pp.227-265.

Triyono dan Jogiyanto Hartono. 2000. Hubungan Kandungan Informasi Arus Kas, Komponen Arus Kas dan Laba dengan Harga atau Return Saham. Jurnal Riset Akuntansi Indonesia. Vol. 3, No. 1. Januari: 54-68.

Prihadi, T. 2010. Analisis Laporan Keuangan: Teori dan Aplikasi.

Riduwan. 2008. Skala Pengukuran Variabel-variabel Penelitian. Cetakan Kelima. ALFABETA: Bandung

Sugiyono. 2004. Metode Penelitian bisnis. CV. Alfabeta: Bandung

Sunariyah. 2004. Pengantar Pengetahuan Pasar Modal. Edisi Keempat, UPP AMP YPKN, Yogyakarta.

Santos, Tano dan Pietro Veronesi. 2010. Habit Information, The Cross Section of Stock Returns and The Cash Flow Risk Puzzle. Journal of Financial Economics Volume 98 : 385-413

Santoso, Singgih. 2010. Aplikasi SPSS pada Statistik Multivariat: Penerbit: Elex Media Komputindo

Sekaran, Uma . 2007. Research Method for Businees, $5^{\text {th }}$ Edition. fJohn Willey \& Sons Inc, N.J

Winarni, Yuli. 2003. Analisis Variabel-variabel yang mempengaruhi Eraning Per Share Pada Perusahaan Tekstil di Bursa Efek Jakrat. Jurnal Ekonomi dan Manajemen. Vol.4, No 1. April.

Wahyuni, Sri. 2002. Analisis Kandungan Informasi Laporan Arus Kas di Bursa Efek Jakarta. Jurnal Ekonomi dan Bisnis Indonesia. Vol. 17, No. 2. Hal 200-210.

Zang, A.Y., 2011. Evidence on the trade-off between real activities manipulation and accrualbased earnings management. The Accounting Review, 87(2), pp.675-703. 